\title{
Mothers' Knowledge for Following Activities of Children in the Health Care Community
}

\author{
$1^{\text {st }}$ Yossy Wijayanti \\ Universitas Muhammadiyah \\ Pringsewu \\ Lampung, Indonesia
}

\author{
$2^{\text {nd }}$ Nurwinda Saputri \\ Universitas Muhammadiyah \\ Pringsewu \\ Lampung, Indonesia \\ nurwindasaputri17@gmail.com
}

\begin{abstract}
Mothers' knowledge in the following activity of children in the health care community. One of community participation in the health scope is the Integrated Service Post (Posyandu). Posyandu is one form of effort in improving community-based health (UKBM) which is managed and conducted from, by and with the community to empower and provide facilities to the community in obtaining basic health services to accelerate the reduction in infant mortality, children and birth rates. The age of children who visit the Posyandu from 1 month to 5 years. The purpose of this study is to find out whether the mother's knowledge about posyandu is related to the mother's behavior in participating in the activities of the children posyandu. The research design used was the analytic method with a crosssectional approach. The sample is all mothers who follow the activities of Posyandu children's, using the Total Sampling technique are 45 respondents. Socioeconomic, education and geographical factor that affect the low number of children's visiting the posyandu. The results obtained by mothers who have knowledge of posyandu are mothers who behaved well in participating in posyandu activities for children 28 people (62.2\%), and mothers who behaved poorly in participating in posyandu activities for children 17 people (37.8\%). Socioeconomic, education and geographical factor that affect the low number of children visiting the posyandu. The analysis using chi-square was obtained $\rho$ value $(0,000)$ $<\alpha(0.05)$. It's mean that there is a correlation between knowledge of posyandu with mother behavior in following the activities of children posyandu. In conclusion the cadre of Posyandu should be increasing the information for children's mother to participated in Posyandu.
\end{abstract}

Keywords-Mothers' Knowledge, Children, Health Care Community

\section{INTRODUCTION}

One of the community's roles in the health sector is the behavior of an Integrated Service Post (Posyandu). Posyandu is a form of effort in community-sourced health (UKBM) which is managed and organized from, by and together with the community to empower and provide facilities to the community in obtain basic health services to accelerate the decline in infant mortality, under-five and birth rates. In addition, so that the community can develop health activities and other support [2]. The age of children who visit the Posyandu from 1 month to 5 years.

The purpose of establishing this Posyandu is to reduce maternal and child mortality [12]. Based on the survey data of the SUPAS Cataract Population, 305 / 100,000 live births were received from 9 ASEAN countries; Indonesia ranked No. 2 with the highest maternal mortality rate. Lift 15 Neonatal deaths per 1,000 live births [4]. Socioeconomic, education and geographical factor that affect the low number of children visiting the posyandu.

Based on the data obtained there are 24 Program Scopes, one of which is the Number of Children Visits to Posyandu, with the target of ignoring visits to the community (34.00\%). Children become the most important part of life because this period is very critical to create quality human beings. Brain cells at this time are experiencing optimal development [3].

The importance of monitoring the growth and development of children is part of preventing the risk of a disease, so the Posyandu provides basic services to optimize the growth and development of children, as for the level of awareness of parents who may not understand the importance of monitoring the growth and development of this child due to several possibilities that can influence the behavior of mothers to follow Toddler Posyandu activities include knowledge, age, family support, and education. Lack of Knowledge is very influential on the factors of one's behavior [1].

The $\mathrm{D} / \mathrm{S}$ indicator data in Bulukarto is $(65.98 \%)$, while in December it was $(28.99 \%)$, the total number of children under five was 350 Toddlers, who had KMS cards (Kartu Menuju Sehat) totaling 307 people, while toddlers who had visited 189 posyandu. This shows that posyandu visits are still low or there is a lack of compliance from mothers visiting.

\section{RESEARCH METHOD}

This research used an analytic survey method with a cross-sectional research design with approach, observation or data collection at the same time, all research subjects are observed at the same time. The population in this study is mothers who have children under five, there are 45 samples selected in this study. Samples were selected according to the inclusion criteria, namely mothers of toddlers who have children aged 0-5 years, mothers of toddlers who take part in posyandu activities, willing to be participants, physically and mentally healthy [8]. The exclusion criteria were mothers of children who could not read and write, toddlers who came to the community health center, not with their mothers, toddlers who had moved and were not members of the posyandu jasmine anymore, children under five who had died. The dependent variable in this 
study is the Mother's Knowledge of Posyandu and the independent variable behavior of mothers in participating in Posyandu activities. This research was allocated in Semeru Posyandu, Pringsewu Lampung Indonesia, conducted in April 2017.

Data collection is done by interviewing directly and by using assessments. Data analysis uses statistical package statistical tests (SPSS). Data were analyzed using frequency, Chi-square test using confidence interval (CI) $95 \%$ and alpha $(\alpha) 0.05$

\section{RESEARCH RESULT AND DISCUSSION}

TABLE 1. CORRELATION OF KNOWLEDGE ABOUT POSYANDU WITH MOTHER'S BEHAVIOR IN FOLLOWING CHILDREN POSYANDU ACTIVITIES IN SEMERU POSYANDU

\begin{tabular}{|c|c|c|c|c|c|c|c|}
\hline & \multicolumn{4}{|c|}{ Mother's Existence } & \multicolumn{2}{|c|}{ Total } & \\
\hline \multirow[t]{2}{*}{$\begin{array}{c}\text { Knowledge } \\
\text { About Posyandu }\end{array}$} & \multicolumn{2}{|c|}{ Well } & Not good & & $\mathrm{N}$ & $\%$ & P-value \\
\hline & $\mathrm{N}$ & $\%$ & $\mathrm{~N}$ & $\%$ & & & \\
\hline Well & 13 & $86,7 \%$ & 2 & $11,8 \%$ & 15 & $100,0 \%$ & 0,000 \\
\hline Enough & 13 & $76,5 \%$ & 4 & $23,5 \%$ & 17 & $100,0 \%$ & \\
\hline Less & 2 & $15,4 \%$ & 11 & $84,6 \%$ & 13 & $100,0 \%$ & \\
\hline TOTAL & 28 & $62,2 \%$ & 17 & $37,8 \%$ & 45 & $100,0 \%$ & \\
\hline
\end{tabular}

Based on table 4.3, we know that mothers who have knowledge about good posyandu will have good behavior in participating in toddler posyandu activities, namely $13(86.7 \%)$ of respondents. Statistical test results obtained $\mathrm{p}$-value $=0,000$ so that $\mathrm{p} \leq \alpha=0.05$ CI $95 \%$ then $\mathrm{Ho}$ is rejected $\mathrm{Ha}$ accepted. This means that the results of the study show that there is a relationship between the Knowledge of Posyandu and Mother's Behavior in Following Toddler's Posyandu Activities in Semeru Posyandu. The results of our cross-sectional study analyzed data on Mother Knowledge about Posyandu by looking at maternal behavioral factors, this activity lasted about 7 days and it was found that the majority of respondents $(86.7 \%)$ made a good visit, one's knowledge could be one factor that usually affects shaping the person and behavior of a person, the higher the knowledge about posyandu, the better the behavior in participating in posyandu activities because they know the benefits and benefits of posyandu activities carried out [6].

This research can be seen that mothers have less knowledge misbehave namely $(84.6 \%)$, while $(11.8 \%)$ of respondents who have good knowledge but not well behaved. Chi-square statistical test results obtained pvalue $=0,000(0,000<0.05)$, it can be concluded that there is a correlation between Mother's Knowledge of Posyandu and Mother's Behavior in Participating in children Posyandu Activities in Semeru Posyandu, Bulukarto Village, Pringsewu Regency 2017. The results of this study are supported by Notoatmodjo (2007) who revealed that knowledge can change behavior in the desired direction.

Posyandu is a basic health activity organized from, by and for the community to be assisted by health workers in a puskesmas working area, where this program can be implemented in hamlet halls, village halls, and other places that are easily visited by the community [11]. Mother's knowledge about posyandu is not only based on education but there are also several factors that influence mother's knowledge about posyandu such as, Exposure to mass media, Economy or income, Social relations and Mother's Experience [7]. Other research states several factors that influence a person's level of knowledge include education and information. Education, in theory, affects the learning process so that people with higher education will more easily receive information from various sources. The higher one's education, the better their knowledge. This knowledge will influence in shaping attitudes and behaviors so that the higher education a person will have positive behavior [10].

The mother's behavior in participating in the Posyandu activities for toddlers is based because the mother's knowledge about posyandu has good knowledge so that the mother's behavior in participating in the Posyandu is good, based on interviews obtained by mothers who have good knowledge and good behavior because they have gotten information about posyandu from Village Midwives or other health workers during counseling so as to be able to answer well questions about the posyandu that researchers provide, while mothers who have good knowledge but bad behavior can be influenced by other factors such as social relationships, beliefs, beliefs, values, availability, affordability of resources power of health services, community priorities and commitments, community leaders, and family support.[9]

This is because if mothers know the benefits and services carried out at the posyandu and the use of toddlers to be brought continuously to the posyandu and the importance of KMS as a tool for recording and observing child health development that is easily done by mothers, then mothers can assess and do something to try to improve and improve the health of their children. This is consistent with the theory that the knowledge a person has is the basis for action because that person's ability to do something depends on the knowledge he has. On the basis of knowledge about posyandu, the objectives and benefits obtained in the posyandu allow mothers to be present at every posyandu implementation.

\section{CONCLUSION}

The findings suggest that knowledge level is part of a factor in the change of mother's behavior in following the activities of children posyandu. Support from the 
family is also very important to help the mother in visiting the children Posyandu, the better the mother's knowledge, the better the behavior of the visit.

\section{REFERENCES}

[1] Adriani, Dian. (2011). Tumbuh Kembang dan Terapi Bermain Pada Anak .Jakarta : Salemba Depkes RI, (2006). Profil Kesehatan Indonesia Tahun 2005. Depkes RI, Jakarta

[2] Dewi, L. N. V. (2010). Asuhan Neonatus Bayi dan Anak Balita. Jakarta : Salemba Medika

[3] Endang L, A. (2017). Kematian Maternal dan Neonatal di Indonesia, Tanggerang

[4] Kresno, S. (2005). Aspek Sosial Budaya Yang Berhubungan Dengan Perilaku Kesehatan. Jakarta: Rineka Cipta.

[5] Mustika dan Nintyasari dian dzkk (2015). Hubungan pengetahuan ibu balita dengan kepatuhan kunjungan balita ke posyandu di desa sumberejo kecamatan mranggen kabupaten demak.

[6] Notoatmodjo, S. (2007). Promosi Kesehatan Dan Ilmu Perilaku. Jakarta : Rineka Cipta

[7] Notoatmodjo, S. (2012). Metodologi penelitian Kesehatan. Jakarta : Rineka Cipta

[8] Nursalam. (2013). Metodologi Penelitian Ilmu Keperawatan. Jakarta : Salemba Medika

[9] Puri K.D.P (2010) Pengetahuan tersebut akan berpengaruh dalam membentuk sikap dan perilaku sehingga semakin tinggi pendidikan seseorang akan memiliki perilaku yang positif. Jurnal Interaksi.

[10] Sulistyorini,dkk. (2010). Posyandu dan desa Siaga. Yogyakarta : Nuha Medika

[11] Wahyuningsih, Dkk. (2009). Dasar-dasar ilmu kesehatan dalam kebidanan. Yogyakarta : Fitramaya 